Artikel Konseptual

Submitted: 4 Mei 2019

Accepted: 28 Juni 2019

Published: 30 Juni 2019

\title{
PEMBELAJARAN SEJARAH KONTEKSTUAL, KREATIF, MENYENANGKAN DI KELAS DENGAN “POWER DIRECTOR” BAGI GENERASI Z
}

\author{
Melaningrum Andarwati
}

melaningruma@gmail.com

SMAN 1 Sumberpucung Malang

Abstract:Today is the era of generation $Z$, a generation that is all connected to the internet. Classroom learning must be innovative by applying the concept of "Learning is fun". Historical teachers in high school must understand the characteristics of Generation $Z$ because students faced in class are generation $Z$. History teachers must innovate to use Gadgets in learning so that history lessons become contextual. Contextual history can evoke historical awareness. The use of device media in learning will increase the power of creativity, skills, productivity, students in learning history. The Power Derector application can be an alternative media for learning history in class, because Power Director can be downloaded either off line or on line. The application is easy to operate for students to make videos, edit images, sounds, photos at the same time. Students can present the past with their creativity, so history becomes contextual and fun. Video results are uploaded easily to Youtube and to other social media. Authentic assessment involving students increase their competency to increase productivity with power director.

Keywords: Generation Z, Power Director, Learning history

\section{PENDAHULUAN}

Pembelajaran sejarah dirancang untuk membekali peserta didik dengan ketrampilan, menenanamkan cara berpikir sejarah, menanamkan kesadaran sejarah, membangun moralitas bangsa Indonesia dengan idiologi Pancasila sebagai warisan luhur menuju 100 tahun Indonesia emas. Pembelajaran sejarah diharapkan membawa atmosfer 
keteladanan para pahlawan dapat melahirkan inspirasi positif guna menangkal karakterkarakter yang tidak sejiwa dengan pandangan hidup bangsa yaitu Pancasila.

Salah satu karakteristik matapelajaran sejarah adalah mempelajarai manusia sebagai makhluk sosial yang dinamis, hidup pada masa kini sebagai kelanjutan dari masa lampau, sehingga pelajaran sejarah memberikan dasar pengetahuan memahami kehidupan masa kini. (Dikdasmen; 2018) melalui media informasi dan telekomunikasi yang berbasis internet masa lampau dapat dihadirkan kembali melalui foto, suara, dan video, ke dunia masa kini sehingga pelajaran sejarah menjadi kontektual dan menyenangkan.

Pembelajaran sejarah dewasa ini pada umumnya masih bersifat pendekatan konvensional dalam pembelajaran peserta didik di kelas, melalui ceramah, tanya jawab dan pemberian tugas, yang masih "behaviorist" atau "strukturalist". Pengajaran sejarah secara tradisional mengakibatkan peserta didik hanya bekerja secara prosedural dan memahami sejarah tanpa penalaran, yang berorientasi pada psikologi perilaku dan strukturalis, lebih menekankan hafalan dan drill merupakan penyiapan yang kurang baik untuk kerja profesional para peserta didik nantinya (Subakti YR;2010).

Kebanyakan guru mengajar dengan menggunakan buku paket sebagai "resep", guru mengajarkan sejarah berdasarkan buku dari halaman per halaman, serta strategi pembelajaran lebih didominasi oleh upaya untuk menyelesaikan materi pembelajaran dalam waktu yang tersedia, dan kurang adanya upaya agar terjadi proses dalam diri peserta didik untuk mencerna materi secara aktif dan konstruktif

Generasi Z merupakan generasi cyber yang lahir sesudah tahun sembilan puluhan. Sekarang mereka telah tumbuh menjadi remaja, lahir dan dibesarkan di era digital, dengan aneka teknologi yang canggih, seperti: laptop, ponsel, tablet pintar, iPad, PDA, MP3 player, BBM, internet, dan aneka perangkat elektronik lainnya. Sejak kecil, siswa saat ini sudah mengenal dan akrab dengan berbagai gawai yang canggih itu.

Kedekatan generasi $Z$ dengan teknologi membuat kehidupan mereka serba terkoneksi dengan internet. Bangsa ini harus siap memasuki era baru, saat milenial menua dan generasi milenial remaja. Dalam mengajar yang dihadapi guru adalah generasi $Z$, guru sejarah harus menerapkan paradikma baru mengajar sejarah secara non konvensional.

Pembelajaran sejarah harus inovatif, mengadaptasi model pembelajaran yang menyenangkan dengan memanfaatkan media Teknologi Informasi dalam pembelajaran di kelas. Peserta didik akan senang belajar apabila model pembelajaran sesuai dengan jiwa 
dan dunianya. Keluh kesah guru di kelas akibat peserta didik tidak fokus dalam pembelajaran dapat dikurangi. Banyak guru enggan merubah paradigma mengajar sejarah secara konvensional, karena memanfaatkan teknologi informatikan dalam pembelajaran yang berbasis internet tidak adanya konektivistas jaringan internet di daerah lingkungan kelas atau sekolah.

Bila paradikma mengajar konvensional tetap digunakan oleh guru dalam pembelajaran sejarah di kelas maka tidak ada artinya perubahan kurikulum yang secanggih apa pun pelajaran sejarah akan menjenuhkan dan tidak menarik bagi peserta didik dan ini akan membahayakan mental generasi muda yang tidak tahu jati diri bangsanya dan akan menjadi obyek imperialisme budaya bangsa lain.

Aplikasi Power Director dapat diunggah melalui SHAREit dan Bluetootth, aplikasi ini dapat mengoptimalkan peserta didik belajar sejarah dengan kreatif, kontektual dan menyenangkan, sehingga peserta didik dapat menghasilkan karya tulis, karya audio visual maupun membuat video sendiri untuk pembelajaran sejarah.

Tulisan ini akan menguraikan tetang karakteristik generasi $\mathrm{Z}$ dan peran guru dalam pembelajaran sejarah di kelas. Aplikasi Power Director dan cara pengoperasiannya dengan online maupun offline, Aplikasi Power Drector dalam pembelajaran sejarah di kelas, dan terakhir membahas tentang cara penilaian pembelajaran sejarah dengan aplikasi Power Director.

\section{KARAKTERISTIK GENERASI Z DAN PERAN GURU DALAM PEMBELAJARAN}

Di era cyber sekarang ini yang dihadapi guru di kelas adalah generasi Z. Sebelum mengajar di kelas, guru sejarah sebaiknya memahami terlebih dahulu karakteristik pelajaran sejarah, memahami karakteristik peserta didik yang dihadapinya. Hakikat mengajar adalah bagaimana peserta didik mau dan senang belajar. Apabila guru sejarah memahami karakteristik peserta didiknya maka guru akan mencari model-model pembelajaran sejarah yang dapat menyenangkan untuk belajar.

Individu Generasi Z ditandai dengan kecanggihan teknologi informatika dan mulkulturalisme, generasi ini lahir antara tahun 1995 sampai dengan 2010. Generasi Z ini memiliki hidup dengan alam internet (Betjkovsky, 2016). Karakteristik unik yang dimiliki generasi Z di antaranya:

JPSI, Vol. 2, No. 1, 2019 
Fasih Teknologi artinya generasi ini lahir gandrung dengan teknologi informasi dengan berbagai aplikasi komputer, Sikap ingin tahu generasi $Z$ sangat tinggi, ketika dihadapkan dengan teknologi, mereka tidak perlu diajari. Generasi Z dengan sendirinya akan berusaha menguasai apa yang dibutuhkan atau apa yang harus dilakukan (Muklis, 2015).

Berkat teknologi, generasi ini dapat mengakses berbagai informasi yang mereka butuhkan secara mudah dan cepat baik dalam bidang pendidikaan maupun kebutuhan sehari-hari. Generasi Z ini juga disebut dengan "Generasi Digital”.

Sosial: Dalam hubungan sosial, Generasi $Z$ ini sangat inten berinteraksi melalui media sosial dengan semua kalanagan khususnya dengan teman sebaya tanpa batas wilayah daerah dan negara misalnya melalui jejaring seperti; Facebook, Twitter atau SMS. Lewat jejaring sosial, Generazi Z menerima informasi yang bermanfaat bagi hidupnya. Beragam perangkat canggih, secara tidak langsung telah merubah pola pikir dan gaya hidup remaja saat ini termasuk cara belajar baik di rumah, di sekolah, maupun di masyarakat. Generasi $Z$ tidak terlibat secara fisik dengan orang lain, tetapi lebih banyak berkomunikasi melalui dunia maya.

Ekspresif: Generasi Z cenderung toleran dengan perbedaan kultur dan sangat peduli lingkungan karena melaui jejaring sosial dapat menerima informasi secara cepat yang bermanfaat bagi hidupnya.

Multitaskhing: Generasi Z terbiasa dengan berbagai aktivitas dalam satu waktu yang bersamaan misalnya, membaca, berbicara, menonton, atau mendengarkan musik. Generasi Z menginginkan segala sesuatu dapat dilakukan berjalan dengan serba cepat tidak menyukai hal-hal yang berbelit-belit. Memiliki sikap senang berbagi dan cepat berpindah dari satu pemikiran atau pekerjaan kemikiran pekerjaan yang lain. Memiliki kemampuan tinggi dalam mengakses dan mengakomodasi informasi sehingga mereka dapat kesempatan lebih banyak dan terbuka untuk mengembangkan dirinya.

Karakter buruk Generasi Z, cenderung kurang sabar, ingin menyelesaikan masalah menggunakan cara-cara instan karena terbiasa berkomunikasi, menyelesaikan masalah melalui dunia maya yang serba cepat dan praktis. Sebagian dari generasi ini kurang terampil berkomunikasi verbal yang bisa menjurus menjadi tidak peduli dengan lingkungan sekitar. Apabila karakter buruk dapat diakamodir dengan baik oleh orang tua, guru dan masyarakat lingkungannya, nilai buruk akan dapat diminimalisir. 
Media pembelajaran yang nyata harus disiapkan. Generasi Z tidak akan menyukai model pembelajaran satu arah. Mereka harus diberi kesempatan mengemukakan pendapat. Generasi Z ini mempunyai konsep berpikir sendiri. Internet telah banyak membentuk pola pikir mereka. Penerapan metode Active Learning membuat peseta didik betah belajar. Remaja Generasi Z tidak akan betah duduk berlama lama mendengarkan penjelasan dari guru yang mengajar dengan metode satu arah.

Sebelum mengajar generasi Z yang cangih dalam teknologi digital, guru sebaiknya memahami karakter sisi baik dan sisi buruk generasi Z ini. Karakter yang ada generasi Z yang baik adalah sikap ingin tahu yang sangat tinggi. Ketika dihadapkan dengan teknologi, mereka tidak perlu diajari. Generasi Z dengan sendirinya akan berusaha menguasai apa yang dibutuhkan atau apa yang harus dilakukan untuk tahu dan mengaplikasikan suatu teknologi.

Dalam pembelajaran, Generasi Z cenderung menyukai hal-hal yang aplikatif dan menyenangkan. Mudahnya memperoleh informasi membuat generasi ini cepat bosan dalam menangkap pelajaran di sekolah yang disampaikan dengan cara konvensional, Inovasi dalam pembelajaran mutlak diperlukan guru harus paham dengan karakter peserta didik sehingga peserta didik senang belajar dan mau belajar untuk mengembangkan dirinya..

Rasa kepekaan dan tanggap teknologi informasi yang dimiliki generasi Z menjadi modal bagi guru untuk membuat model pembelajaran yang dapat mengekploitasi kemampuan peserta didik untuk mandiri, menumbuhkan semangat berkreasi dan mencipta. Tugas guru mendesain pembelajaran yang dapat mengaktifkan peserta didik untuk meningkat kompetensinya, baik dari sikap, pengetahuan, maupun ketrampilan, mengarahkan mereka memanfaatkan media sosial untuk mengkomunikasikan hasil karya mereka, misalnya dengan menulis blog dan membuat youtube.

Guru harus meninggalkan cara pembelajaran yang konvensional yang berpusat pada guru, diubah dengan sistem pembelajaran yang berpusat pada peseta didik. Guru berperan sebagai penghantar para peseta didik untuk mengembangkan kreativitas, mengembangkan semangat kemandirian, integritas, membangkitkan kepercayaan diri, menyakinkan para peseta didik, bahwa mereka mampu menciptakan karya. Peserta didik perlu terus dimotivasi agar tekun dan fokus dalam suatu pekerjaan dan cita-cita.

Kegiatan pembelajaran di sekolah yang sesuai dengan psikologi dan karakteristik peseta didik akan menjadi dasar bagi keberhasilan generasi $Z$ untuk sukses di masyarakat. 
Pemberian tugas oleh guru yang berbasis teknologi informatika berbasis internet akan lebih memperdalam pemahaman akan penegetahuan yang diajarkan di sekolah karena peseta didik akan mempraktekkan secara langsung apa yang mereka pelajari sesuai dengan jiwa mereka dengan demikian dapat meminimalisir pengaruh buruk dari kemajuan teknologi informasi cyber saat ini.

Pembelajaran yang konvensional yang bertolak belakang dengan karakter generasi Z, akan menyebabkan peserta didik tertekan dan malas belajar di sekolah dan beralih pada kegiatan yang menjatuhkan mereka pada dampak negatif dari media informasi di antaranya game online dan membentuk geng yang rawan pengaruh narkoba sehingga jiwa kreatif mereka tidak dapat tersalurkan.

\section{PEMBELAJARAN SEJARAH KONTEKTUAL, KREATIF, DAN MENYENANGKAN DI KELAS}

"Janganlah melihat ke masa depan dengan mata buta. Masa yang lampau sangat berguna sebagai kaca benggala dari pada masa yang akan datang." Demikianlah salah satu kata bijak Ir. Soekarno, mengapa Sang Proklamator Soekarno dikagumi, karena beliau paham benar bagaimana perjalanan sejarah bangsanya. Untuk menjadi negara yang besar belajar sejarah adalah syarat mutlak. Karena sejarah mengajarkan pengalaman dan kebajikan terhadap umat manusia (Ratnawati:2019). Karakteristik pembelajaran sejarah harus membangkitkan kesadaran nasional pada peserta didik yang memiliki sikap percaya diri sebagai bangsa yang bermartabat seperti leluhurnya. Sejarah harus diajarkan secara kontektual di kelas.

Pembelajaran sejarah kontektual dapat dilakukan dengan mengajak peserta didik mencari gambar, foto, rekaman suara dan film masa lalu. Gambar dan foto memiliki makna yang lebih baik dibandingkan dengan tulisan. Foto atau gambar sebagai bahan ajar tentu diperlukan satu rancangan yang baik agar selesai melihat serangkaian gambar atau foto peserta didik dapat melakukan sesuatu yang pada akhirnya menguasai satu Kopetensi Dasar atau lebih (DEPDIKNAS, 2008)

Model pembelajaran sejarah sesuai dengan kurikulum 2013 yang disempurnakan tahun 2017, yaitu model yang dikembangkan dalam pembelajaran harus dapat men- 
dorong dan memotivasi peserta didik untuk mengembangkan ide dan kreativitasnya sehingga pembelajaran lebih interaktif, menyenangkan dan dan inspiratif, model pembelajaran dapat mendorong peserta didik untuk berpartisipasi aktif dalam diskusi dan kegiatan yang dapat meningkatkan kepercayan diri pada peseta didik (Dipdasmen, 2018)

Sejarah merupakan rekonstruksi kehidupan umat manusia yang ada pada masa lalu tentang suatu peristiwa dalam dimensi waktu dan tempat (Kuntowijoyo, 1995). Ada dua sifat sejarah yang pertama sejarah harus dinarasi agar diketahui bagaimana dapat dimengerti dan dipahami oleh pembacanya. Sejarah naratif membuat gambaran tentang masa lampau, merekonstruksi apa yang terjadi diuraikan, kejadian-kejadian penting diseleksi dan diatur menurut poros waktu yang tersusun sebagai cerita.

Kedua sejarah non-naratif merupakan peristiwa sejarah yang dianalisis dan dideskripsikan dengan menggunakan pendekatan ilmu-ilmu sosial lebih menitikberatkan pada problem-oriented dengan menggunakan konsep ilmu sosial yang mencoba mengungkap pelbagai tingkat atau dimensi dari realitas sejarah (Kartodirdjo, 1993: 9).

Keduanya sama obyeknya adalah bercerita tentang masa lampau, hanya saja sejarah non-naratif cenderung lebih memperluas penelitian kearah masalah-masalah sosial dan ekonomi daripada masalah politik belaka. Berkaitan dengan sejarah naratif maupun sejarah non-naratif sejarah harus diajarkan secara kontektualisasi yaitu pembelajaran sejarah yang dikaitkan pada masa kini. Membangkitkan kesadaran pada peserta didik di era cyber ini untuk menulusuri jati diri bangsa Indonesia dan peserta didik sebagai bagian di dalamnya.

Bagaimana cara menggali kesadaran sejarah pada peserta didik, yaitu dengan mengajarkan sejarah secara kontektual. Ada beberapa cara melakukan kontekstualisasi mata pelajaran sejarah yaitu; (1) pemanfaatan lingkungan dan fenomena sebagai sumber belajar; (2) pemanfaatan teknologi informasi; dan (3) pemanfaatan buku teks dan LKS (Kemendiknas, 2016).

Kontekstualisasi pembelajaran sejarah dengan memanfaatan lingkungan dan fenomena yaitu menggunakan sumber-sumber belajar sejarah yang ada di lingkungan seperti situs peninggalan sejarah atau lingkungan alam yang ada di sekitar sekolah atau lingkungan terdekat dan memiliki keterkaitan dengan materi sejarah. Misalnya di dekat sekolah terdapat museum, situs sejarah, hutan yang 'disakralkan', bangunan-bangunan sejarah, dan sebagainya. 
Dalam lingkungan tersebut dapat pula menunjukkan adanya fenomena sejarah di masa lalu yang ada kemiripan dengan masa sekarang. Misalnya peninggalan tata kota pada kota-kota tua di masa lalu dan pengelolaan lingkungannya dengan penataan kota di masa sekarang. Bahkan juga dari tata kota tersebut bisa dilihat bagaimana masyarakat masa lalu memelihara lingkungan alam yang penuh dengan kearifan lokal bisa dikaitkan dengan pelestarian lingkungan masa sekarang.

Pemanfaatan teknologi informasi merupakan salah satu cara yang dapat dilakukan guru di kelas agar pembelajaran sejarah menjadi kontekstual dan menarik. Teknologi informasi yang digunakan dapat berupa informasi dari link terkait (misalnya google), film dokumenter, foto-foto sejarah, video sejarah, perpustakaan digital dan museum digital.

Penggunaan teknologi informasi akan menjadi kontekstual dengan menampilkan materi sejarah menjadi hidup, seolah-olah hadir pada saat ini dan tidak terjebak pada pengolahan materi yang bersifat verbalistik seperti metode ceramah. Pemanfaatan teknologi informasi disesuaikan dengan situasi dan kondisi daerah dimana satuan pendidikan itu berada.

Sejarah adalah fakta dapat dibuktikan oleh peserta didik dengan melibatkan peserta didik mencari fakta, data, dengan teknologi berbasis internet. Peserta didik menggali fakta, dan data sejarah mengunggahnya dalam bentuk narasi dan kreativtas dengan membuat video sehingga fakta sejarah dapat hidup pada masa kini,melalui jaringan internet dengan menggunakan gawai.

Pembelajaran sejarah di kelas seharusanya sudah meninggalkan cara-cara konvensional dan diubah menjadi non konvensional dengan memanfaatkan teknologi informasi yang dapat membantu guru untuk berinovasi dalam pembelajaran sejarah, sehingga peserta didik akan tumbuh jiwa kreatifitasnya, aktif, mandiri dan produktif yang membangkitkan kepercayaan diri kuat dan tangguh sebagai bangsa yang besar.

\section{POWER DIRECTOR DAN CARA PENGOPERASIANNYA}

Power Director adalah program pengeditan video digital untuk membantu membuat film video digital yang terlihat profesional dengan tanyangan slide foto, lengkap dengan musik, suara, efek khusus, efek transmisi dan banyak lagi. Power Director dapat mengeksport proyek ke file, camcorder, perangkat portebel, yang dapat langsung diunggah di berbagai situs web video, daring atau ke disket (Gebruikershandleiding, 2012). JPSI, Vol. 2, No. 1, 2019 
Power Director merupakan deretan aplikasi edit video terbaik untuk ponsel android yang kelasnya sudah semi profesional (Purwoko, 2019).

Aplikasi Power Dairector dalam pembelajaran dapat memotivasi mengembangkan semangat untuk berkreatifitas terutama dalam memanfaatkan perangkat gawai. Keistimewaan dari aplikasi ini adalah mudah dioperasikan oleh para peseta didik maupun guru pengajar. Tanpa menggunakan jaringan internet yang aktif, produk media tetap bisa diunggah dengan syarat ada yang telah memiliki aplikasi ini. Aplikasi ini sudah bisa dibagikan dengan aplikasi Share IT atau Bluetooth langsung bisa diberikan dari guru ke peseta didik. Power Director dapat juga diunduh melalui laman Playstore dengan jaringan internet.

Power Director merupakan cara mudah untuk mengedit video dapat menggunakan tablet maupun ponsel yang masih belajar untuk membuat video yang bagus, enak dilihat dengan peralatan yang banyak dimiliki peserta didik dengan android. Bagi pemula, video editor Power Director sangat mudah digunakan. Tidak perlu waktu lama untuk mempelajari video editor ini, karena ada video tutorialnya. Jadi sebelum memakai kita bisa melihat dan mempelajari tutorialnya.

Fitur- fitur dalam Power Director sebagai berikut; Efek dari partikel sepenuhnya dapat disesuaikan efek, untuk menambahkan objek partikel salju, debu, benda jatuh, editor. Peningkatan slideshow sepenuhnya dapat disesuaikan kamera, 3D, alokasi dan gerakan melalui editor slideshow. Peningkatan video yang terbaik dengan memodifikasi video untuk tanam, rotasi, mengubah kecepatan atau pemutaran terbalik. Perbaikan melalui stabilisasi video, menyesuaikan pencahayaan dan meningkatkan kualitas video teknologi TrueTheater (Rubbish, 2016).

Penghapusan di file video dan audio juga bisa. Mudah juga dalam memperbaiki efek ICC yang diiinginkan. Dapat menambahkan daftar musik, baris waktu sampai tiga judul musik yang terpisah dalam video secara bersamaan. Sepenuhnya extensible user interface digunakan untuk mengedit kebutuhan. Video pada layar penuh dalam tampilan multimedia dapat melihat video pada perangkat tampilan tunggal atau kamera video ketika mengaktifkan dual display. Gunakan berbagai seleksi untuk memilih segmen media pada timeline untuk kopirvoaniya atau menghapusnya dari proyek tersebut. Gunakan garis grid untuk membantu dalam penempatan yang tepat dari judul ICC dan multimedia. New Workspace digunakan untuk ruang kerja, yang membuat menemukan video lebih cepat. Optimized CPU / GPU menyediakan kecepatan tinggi pengolahan konten video HD. 
Menambahkan beberapa judul pada video yang dibuat oleh disk. Membuat slideshow dapat dilihat seluruh struktur disk. Menu multi-level digunakan untuk mengedit menu. Efek loading lebih cepat dan lebih mudah dan template dari Director Zone situs web. Director Zone situs Web juga memuat efek ICC, template, judul, partikel efek dan template menu DVD. Sepenuhnya terintegrasi ke dalam penggunaan Cyber Link Power Director untuk efek mencari template. Jumlah akses untuk memperbaiki proyek dari negara lain melalui DirectorZone situs Web. Shutdown digunakan setelah membuat video atau merekam ke disk untuk menghemat energi.

Langkah-langkah pengoperasian Power Director

1. Menggabungkan video: pertama-tama harus membuat judul atau nama video yang akan kita buat, selanjutnya kita langsung memilih video yang akan kita gabung. Caranya dengan mengklik dua kali video yang dipilih, otomatis akan muncul di bawah (lihat gambar dibawah). Kalau mau tambah video lagi, tinggal klik dua kali.

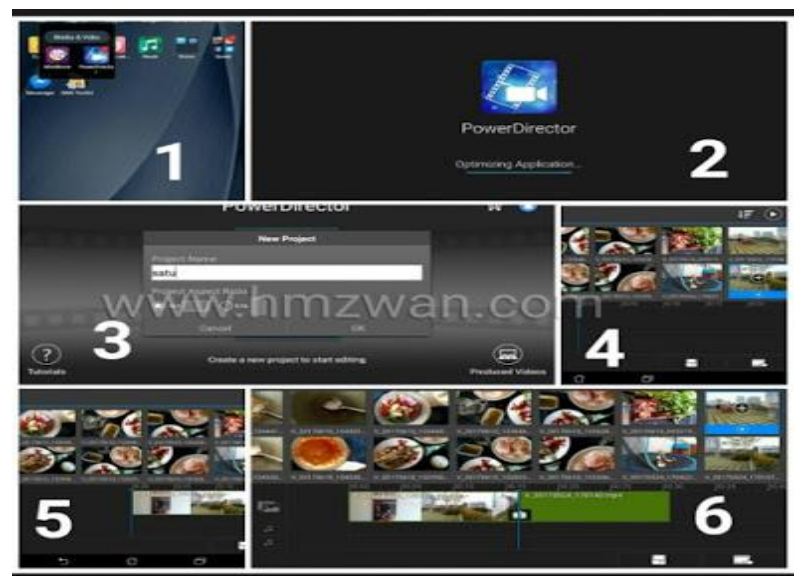

Gambar 1. Tampilan Power director

2. Memberi tulisan: Klik ikon nomor 2 yang ada di sebelah pojok kiri, pilih $T$ title, kemudian akan keluar pilihan tulisan yang nantinya akan muncul di video. Klik dua kali, akan muncul kotak di bawah video yang dipilih, klik dua kali, tulis. Kalau mau pilih font dan lain sebagainya, klik ikon no 1, klik Title Designer, tinggal pilih. 


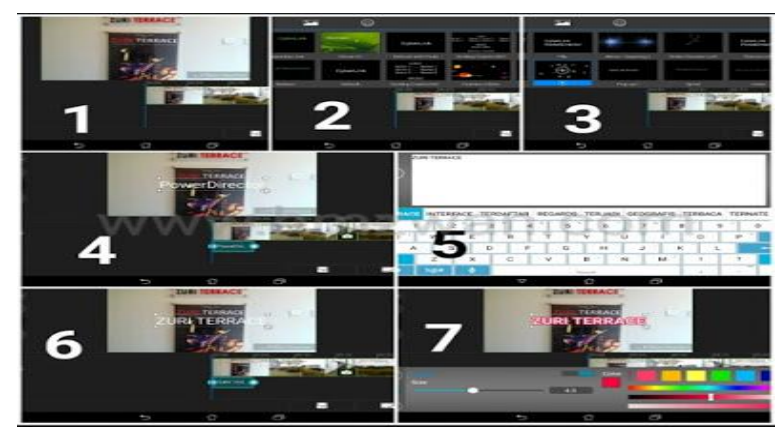

Gambar 2. Memberi tulisan

3. Efek pergantian dari video satu ke video berikutnya

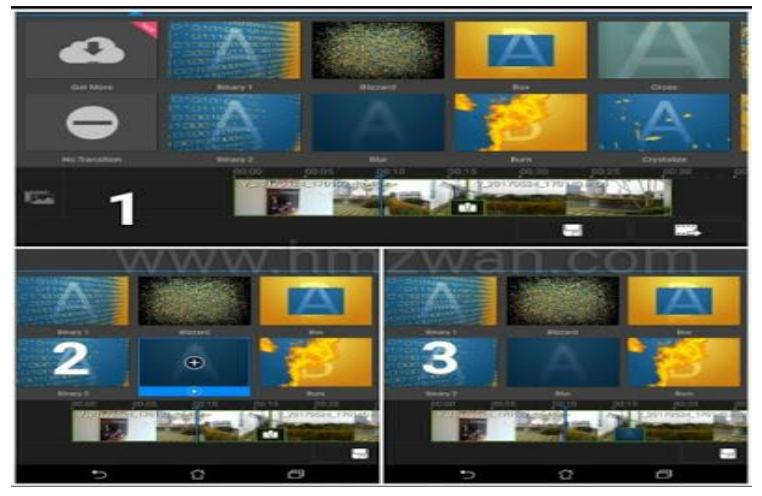

Gambar 3. Memberikan efek

4. Memberi musik

Klik ikon no 1 yang ada di sebelah pojok kiri, tinggal pilih musik yang disuka. Caranya dengan mengklik dua kali musik yang kita pilih, otomatis musik langsung muncul di bawah video. Kalau mau tambah, tinggal klik lagi. Kalau musiknya terlalu panjang, tinggal geser ke kiri disesuaikan dengan durasi video. Kalau mencoba mendengarkan, klik play. 


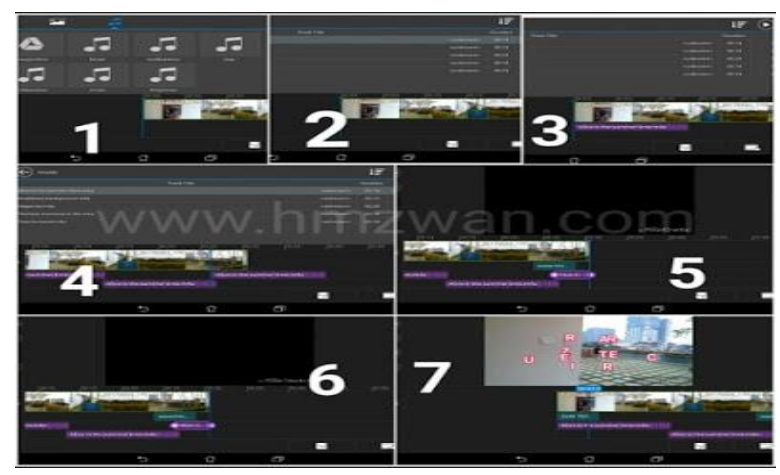

Gambar 4. Memberi musik

5. Menyimpan video

Kalau sudah selesai mengedit video, tinggal menyimpan, klik ikon gambar disket di bagian bawah sebelah kanan. menyimpan di galeri atau langsung di unggah ke youtube, facebook tinggal klik ikon di samping kanan gambar disket. Tinggal klik sesuai yang kita inginkan.

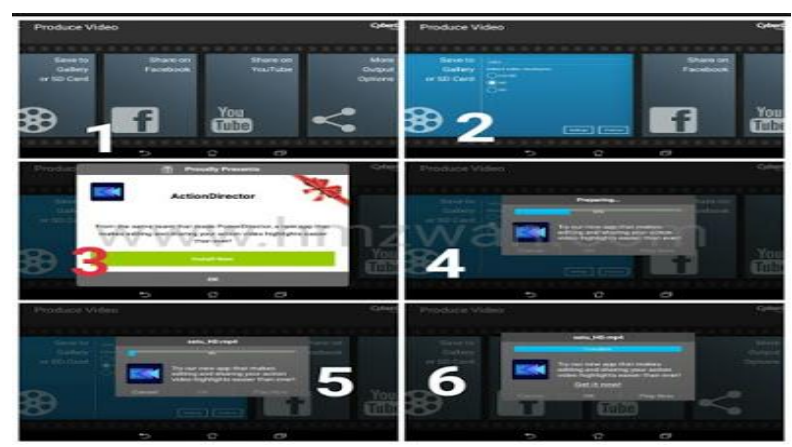

Gambar 5. Menyimpan video

Untuk mendapatkan panduan tutorial, harus terhubung dengan jaringan internet.

\section{APLIKASI POWER DRECTOR DALAM PEMBELAJARAN SEJARAH DI KELAS}

Bagaimana cara pembelajaran sejarah dengan aplikasi Power Director di kelas? Sebelum menerapkan pembelajaran ini, langkah-langkah yang harus dipersiapkan guru 
adalah mengunduh aplikasi Power Director, mengoperasikannya dengan bantuan tutorial yang ada dalam aplikasi ini, mengoperasikan aplikasi ini dengan ponsel sebelum pembelajaran di kelas, aplikasi praktis dan mudah penggunaannya dengan ponsel.

Seluruh kegiatan belajar mengajar di kelas dsusun dalam bentuk Rencana Pelaksanaan Pembelajaran dengan menentukan kopetensi dasar, kelas, program, waktu dan materi pembelajaran serta menentukan langkah-langkah pembelajaran.Sebelum memulai pembelajaran, guru memberikan informasi terlebih dahulu tentang cara kerja Power Director, membagikan aplikasi Power Diretctor ke seluruh peserta didik melalui SHRAEit, setiap peserta didik yang telah menerima aplikasi Power Director wajib membagikan aplikasi ke temannya. Harus dipastikan seluruh peseta didik sudah memiliki aplikasi Power Director di kelas saat pembelajaran .

Melaksanakan pembelajaran, langkah berikutnya guru memberikan informasi cara kerja dan penggunaan Power Director ke seluruh peseta didik dan guru mendampingi peserta didik dan memastikan setiap peseta didik sudah bisa mengikuti informasi guru. Peserta didik yang sudah bisa mengoperasikan aplikasi ini diminta untuk membantu teman di kelasnya. Hal ini untuk melatih peseta didik agar dapat bekerjasama, kepekaan sosial dan berbagi dengan sesama temannya.

Dipastikan seluruh peserta didik sudah dapat mengoperasikan Power Director, guru menulis kompetensi dasar yang hendak dicapai di papan tulis peserta didik diminta membuka buku sumber dan bahan literasi eletronik untuk membahas materi menulis teks yang hendak dicapai dalam kompetensi dasar; misalnya Kopetensi Dasar kelas XII IPS Sejarah semester 1 yaitu Peran aktif Bangsa Indonesia pada masa Perang Dingin dan dampaknya terhadap politik dan ekonomi global.

Setiap peseta didik dibagi dalam kelompok masing-masing kelompok beranggotakan dua orang untuk membuat slide video tentang peran aktif bangsa Indonesia pada masa perang dingin setiap peseta didik diberi kebebasan untuk menulis dan membuat kreativitasnya tentang peran aktif bangsa Indonesia pada masa perang dingin

Sebelum menerapkan aplikasi disusun terlebih dahulu rencana pelaksanaan pembelajaran. Perlu diperhatikan alokasi waktu pada saat penyusunan rencana pelaksanaan pembelajaran untuk mata pelajaran sejarah program IPS kelas XII waktunya 4 jam pelajaran tatap muka, setiap 1 jam tatap muka lamanya 45 menit. Waktu 180 menit cukup bagi peserta didik untuk mengekplorasi bahan pembelajaran, menyusun teks, gambar, foto 
mengisi musik bahkan dapat mengisi suara dalam audio di video dan dapat langsung mendapatkan penilaian.

Berdasarkan pengalaman penulis, pembukaan dan membagikan aplikasi Power Director sekitar 15 menit peseta didik diminta membuat konsep dulu agar materi yang divisualkan semua sudah tercakup proses pendalaman materi dan membuat hasil karya audio visual diberikan waktu 90 menit, 60 menit presentasi hasil kerja dengan LCD sekaligus 10 menit untuk kesimpulan dan penutup waktu. Materi disesuaikan sehingga dapat tepat disusun alokasi waktunya.

Pada Kopetensi Dasar contoh di atas waktunya 4 X 45 menit sehingga peserta didik leluasa mencari sumber, menulis materi, dan mencari gambar yang sesuai dengan materi pembelajaran. Untuk menerapkan aplikasi ini dalam pembelajaran sejarah harus diperhitungkan antara materi, waktu dan kemampuan peseta didik di kelas guru harus sudah memahami karakter belajar peserta didiknya.

Langkah selanjutnya, membuat evaluasi dari hasil kinerja peseta didik. Berdasarkan pengamatan yang dilakukan penulis, dengan menerapkan pembelajaran model ini peserta didik dapat belajar mandiri, kelihatan asyik dan mampu menyelesaikan tugasnya masing-masing tanpa banyak bicara, bahkan antar peseta didik saling memberikan informasi dan masing-masing menunjukan kreativitasnya pada temannya dengan rasa senang dan girang.

Dalam proses menciptakan kreativitasnya, peserta didik saling membantu dalam menghasilkan karya. Misalnya ada yang hanya bisa menulis tapi tidak bisa masukan gambar, musik dan, suara teman-temannya membantu mereka dengan suka rela. Penulis merasakan bahwa mereka kompak mengembangkan diri tanpa ada rasa bersaing dan antusias. Penggunaan aplikasi Power Director dalam pembelajaran sejarah di kelas telah penulis terapkan di kelas XII program IPS SMAN 1 Sumberpucung Malang. Dari jumlah peserta didik sebanyak 160 orang.

\section{CARA PENILAIAN PEMBELAJARAN SEJARAH DENGAN APLIKASI POWER DIRECTOR DI KELAS}

Penilaian autentik digunakan untuk mengumpulkan informasi atau data proses, dan hasil belajar speserta didik. Pengumpulan informasi sebagai cara untuk penilaian 
kemajuan hasil belajar peserta didik dalam pencapaian standar kopetensi dan opetensi dasar (Komalasari, 2013).

Penilaian autentik memiliki relevansi kuat terhadap pendekatan ilmiah (scientific approach) dalam pembelajaran sesuai dengan tuntutan kurikulum 2013. Penilaian autentik mampu menggambarkan peningkatan hasil belajar peserta didik, baik dalam rangka mengamati, menanya, mengumpulkan sumber, menalar/mengasosiasi, atau mengomunikasikan. Penilaian autentik cenderung fokus pada tugas-tugas kompleks atau kontekstual, memungkinkan peserta didik untuk menunjukkan kompetensi yang meliputi sikap, pengetahuan, dan keterampilan (Kemendikbud, 2017).

Dalam pembelajaran sejarah memanfaatkan aplikasi Power Director ini, penilaian yang dapat digunakan teknik penilaian pengetahuan dengan memberi penugasan pada peserta didik dengan membuat ringkasan materi yang dibahas sesuai dengan Kompetensi Dasar yang harus dicapai, disesuaikan dengan Rencana Pelaksanaan Pembelajaran.

Ringkasan materi dapat berbentuk teks maupun pengisi suara yang diisi oleh suara peserta didik sendiri. Misalnya pembahasan tentang Kopetensi Dasar kelas XII IPS Sejarah semester 1 yaitu Peran Aktif Bangsa Indonesia Pada Masa Perang Dingin dan Dampaknya Terhadap Politik, Ekonomi Global, peserta didik harus bisa menguraikan apa itu perang dingin, pengaruhnya di bidang politik, ekonomi, bagi dunia dan bagi Indonesia, yang diaudiovisualkan dalam bentuk video dengan aplikasi Power Director.

Contoh rubrik penilaian pengetahuan untuk peran aktif bangsa Indonesia pada masa Perang Dingin dan dampaknya terhadap politik dan ekonomi global sebagai berikut, kejelasan kronologis, dimensi waktu, tempat, peristiwa, tokoh-tokoh yang terlibat. Skor yang diberikan untuk setiap item 1-5.

Tabel 1. Rubrik penilaian pengetahuan

\begin{tabular}{|c|c|c|c|c|c|c|c|c|c|}
\hline \multirow{3}{*}{ No. } & \multirow{3}{*}{$\begin{array}{l}\text { Nama } \\
\text { Siswa }\end{array}$} & \multicolumn{5}{|c|}{ Aspek pengetahuan } & \multirow{3}{*}{$\begin{array}{l}\Sigma \\
\text { Sko } \\
r\end{array}$} & \multirow{3}{*}{ Nilai } & \multirow{3}{*}{ Ket. } \\
\hline & & Kronologis & $\begin{array}{l}\text { Kejela- } \\
\text { san ma- } \\
\text { teri }\end{array}$ & $\begin{array}{l}\text { Demensi } \\
\text { wak- } \\
\text { tutempat }\end{array}$ & $\begin{array}{l}\text { Peri- } \\
\text { stiwa }\end{array}$ & $\begin{array}{l}\text { Tokoh } \\
\text { yang } \\
\text { terlibat }\end{array}$ & & & \\
\hline & & Skor 1-4 & Skor 1-4 & Skor 1-4 & Skor 1-4 & $\begin{array}{l}\text { Skor 1- } \\
4\end{array}$ & & & \\
\hline
\end{tabular}

1.

2.

3.

JPSI, Vol. 2, No. 1, 2019 
Teknik penilaian praktek menggunakan penilaian ketrampilan berupa unjuk kerja yaitu penilaian yang dilakukan oleh guru selama proses pembelajaran berlangsung. Penilaian praktek dimulai dari peserta didik mengunggah aplikasi, mengoperasikan Power Director, memperbaiki gambar, memasukan suara, presentasi sampai samapai menanyangkan hasil karya video melalui LCD. Peserta didik yang tidak responsif tidak dapat mengunggah dalam waktu yang ditentukan nilainya diberikan batas skor minimal.

Peserta didik dilibatkan dalam penilaian, setiap kelompok yang beranggotakan dua orang harus memberikan penilaian dari hasil kerja kelompok lainya tujuannya untuk mendapatkan penilaian yang obyektif. Rubrik penilaian sudah disiapkan guru peserta didik hanya memasukan skor. Penilaian yang melibatkan peserta didik ini dilakukan pada saat presentasi baik untuk penilaian pengetahuan maupun penilaian ketrampilan.

Tabel 2. Rubrik peilaian

\begin{tabular}{|c|c|c|c|c|c|c|c|c|c|}
\hline \multirow{3}{*}{ No. } & \multirow{3}{*}{$\begin{array}{l}\text { Nama } \\
\text { Siswa }\end{array}$} & \multicolumn{5}{|c|}{ Aspek pengetahuan } & \multirow{3}{*}{$\begin{array}{l}\Sigma \\
\text { Sko } \\
r\end{array}$} & \multirow{3}{*}{$\begin{array}{l}\text { Nila } \\
\text { i }\end{array}$} & \multirow{3}{*}{ Ket. } \\
\hline & & \multirow[t]{2}{*}{$\begin{array}{l}\text { Kreatifitas } \\
\text { Skor 1-4 }\end{array}$} & $\begin{array}{l}\text { Pengedita } \\
\text { n gambar }\end{array}$ & $\begin{array}{l}\text { Pengedita } \\
\mathrm{n} \text { audio }\end{array}$ & Peristiwa & $\begin{array}{l}\text { Toko } \\
\mathrm{h}\end{array}$ & & & \\
\hline & & & Skor 1-4 & Skor 1-4 & Skor 1-4 & $\begin{array}{l}\text { terli- } \\
\text { bat } \\
\text { Skor } \\
1-4\end{array}$ & & & \\
\hline 1. & & & & & & & & & \\
\hline 2. & & & & & & & & & \\
\hline 3. & & & & & & & & & \\
\hline
\end{tabular}

\section{SIMPULAN}

Di era milineal dewasa ini, inovasi pembelajaran sejarah sangat diperlukan untuk memahami Remaja Generasi Z yang unik dan penuh tantangan. Guru kelas yang dihadapi adalah generasi $Z$, generasi yang canggih akan internet. Guru harus tanggap, akan karakteristik generasi $Z$, cara-cara pembelajaran sejarah konvensional harus ditinggalkan. Pelajaran sejarah harus kontektual, peran guru sejarah sebagai motivator, dinamisator dan fasilitator dalam kelas saat mengajar harus dikuatkan agar peserta didik dapat 
mengembangkan sikap mandiri, kreatif, inovatif, produktif dan memiliki kesadaran sejarah yang kuat dan tangguh.

Aplikasi Power Director merupakan aplikasi untuk pengeditan gambar, foto, teks, dan suara dijadikan video. Aplikasi ini mudah diunggah dan dioperasikan oleh peserta didik walau tanpa koneksi dengan jaringan internet, gambar, tulisan, teks rekaman suara di masa lampau dapat dilihat pada masa kini, dengan aplikasi Power Director ini membantu pembelajaran sejarah menjadi kontektual.

Berdasarkan pengalaman penulis, menerapkan pembelajaran sejarah dengan aplikasi Power Director ini, di kelas XII program IPS dari sejumlah 165 peserta didik atau 90 $\%$ senang dengan model pembelajaran ini. Pembelajaran ini menggunakan penilaian penugasan dan unjuk kerja. Hal ini menarik karena dalam penilaian peserta didik dilibatkan menilai video hasil kreativitas temannya.

\section{DAFTAR RUJUKAN}

Betjkovsky, J.(2016). Generation; TheBoby Boomer,X,Y, and Z in the Context of Human Capital Management Of The 21 Century In Selected Corporations in The Czek Republic ; Litera Scripta.The Intitute Of Technology an Business in Ceske Bude Jovice :2016-12-20

Depdiknas. (2008). Panduan Pengembangan Bahan Ajar. Jakarta: Departemen Pendidikan Nasional Depaertemen Pendidikan Nasiona Dirjend Manajemen Pendidikan Dasar dan Menengah Direktorat Pembinaan Sekolah Menengah Atas.

Dikdasmen. (2018). Modul Pelatihan Implementasi Kurikulum 2013 SMA Tahun 2018. Jakarta: Direktorat Pembinaan Sekolah Menengah Atas

Gebruikershandleiding. (2012). Power Director, New Taipei City231. Taiwan: Cyber Link Coorperation.

Hmzwan. (2017). Cara Mudah Mengedit Video Menggunakan Power Director: http://www.hmzwan.com/2017/06/cara-mudah-mengedit-videomenggunakan.html

Kemendikbud. (2016). Silabus Mata Pelajaran Sekolah Menengah Atas/Madarasah Aliyah (SMA/MA). Mata Pelajaran Sejarah.Jakarta: Kementrian Pendidikan dan Kebudayaan Nasional. 
Komalasari, K. (2013). Pembelajaran Kountektual Konsep dan Aplikasinya. Bandung: Refika Aditama.

Kuntowijoyo. (1995). Pengantar Ilmu Sejarah. Yogyakarta: Bentang Budaya.

Rubbish. (2015). Fitur-Fitur Power Director : http://delagoas.blogspot.com/2015/03/fitur-fitur-powerdirector.html

Muklis, H.(2015). Pahami Generasi Remaja Z; AFMagazine Education and Lifestyle edisi.November 2015

Purwoko, A. (2019) .Rekomendasi Aplikasi Edit Video Terbaik di HP Android ; https://jalantikus.com/tips/aplikasi-editing-video-terbaik-di-android/ Tautan berhasil disalin diunduh tanggal 26 Maret 201919.03

Ratnawati. (2019). Kontinuitas Sejarah di Era Generasi Z; https://www.malangpost.com/netizen/opini/kontinuitas-sejarah-di-era-generasi-z?st.Published on Saturday, 16 February 2019 19:07

Kartodrdjo,S.(1993). Pendekatan Ilmu Sosial dalam Metodologi Sejarah. Jakarta: PT Gramedia Pustaka Utama.

Subakti, YR. (2010). Paradikma Belajar Sejarah Berbasis Kontruktivisme; SPSS; Vol 24, No 1 April 2010 